\title{
Energy Storage Technology Development for Space Exploration
}

Carolyn R. Mercer, Amy L. Jankovsky, Concha M. Reid, Thomas B. Miller, and Mark A. Hoberecht

Glenn Research Center, Cleveland, Ohio 


\section{NASA STI Program . . . in Profile}

Since its founding, NASA has been dedicated to the advancement of aeronautics and space science. The NASA Scientific and Technical Information (STI) program plays a key part in helping NASA maintain this important role.

The NASA STI Program operates under the auspices of the Agency Chief Information Officer. It collects, organizes, provides for archiving, and disseminates NASA's STI. The NASA STI program provides access to the NASA Aeronautics and Space Database and its public interface, the NASA Technical Reports Server, thus providing one of the largest collections of aeronautical and space science STI in the world. Results are published in both non-NASA channels and by NASA in the NASA STI Report Series, which includes the following report types:

- TECHNICAL PUBLICATION. Reports of completed research or a major significant phase of research that present the results of NASA programs and include extensive data or theoretical analysis. Includes compilations of significant scientific and technical data and information deemed to be of continuing reference value. NASA counterpart of peer-reviewed formal professional papers but has less stringent limitations on manuscript length and extent of graphic presentations.

- TECHNICAL MEMORANDUM. Scientific and technical findings that are preliminary or of specialized interest, e.g., quick release reports, working papers, and bibliographies that contain minimal annotation. Does not contain extensive analysis.

- CONTRACTOR REPORT. Scientific and technical findings by NASA-sponsored contractors and grantees.
- CONFERENCE PUBLICATION. Collected papers from scientific and technical conferences, symposia, seminars, or other meetings sponsored or cosponsored by NASA.

- SPECIAL PUBLICATION. Scientific, technical, or historical information from NASA programs, projects, and missions, often concerned with subjects having substantial public interest.

- TECHNICAL TRANSLATION. Englishlanguage translations of foreign scientific and technical material pertinent to NASA's mission.

Specialized services also include creating custom thesauri, building customized databases, organizing and publishing research results.

For more information about the NASA STI program, see the following:

- Access the NASA STI program home page at http://www.sti.nasa.gov

- E-mail your question via the Internet to help@ sti.nasa.gov

- Fax your question to the NASA STI Help Desk at 443-757-5803

- Telephone the NASA STI Help Desk at 443-757-5802

- Write to: NASA Center for AeroSpace Information (CASI) 7115 Standard Drive Hanover, MD 21076-1320 


\section{Energy Storage Technology Development for Space Exploration}

Carolyn R. Mercer, Amy L. Jankovsky, Concha M. Reid, Thomas B. Miller, and Mark A. Hoberecht

Glenn Research Center, Cleveland, Ohio

Prepared for the

Space 2010 Conference and Exposition

sponsored by the American Institute of Aeronautics and Astronautics

Anaheim, California, August 30 to September 2, 2010

National Aeronautics and

Space Administration

Glenn Research Center

Cleveland, Ohio 44135 


\section{Acknowledgments}

We gratefully acknowledge the support of NASA's Exploration Technology Development Program for funding the Energy Storage

Project to conduct this work, with particular thanks to Diane Hope and Frank Peri. We appreciate the many members of NASA's Constellation Program for many fruitful discussions regarding technical goals and objectives, particularly to David Westheimer, Rob Button, Pat George, Lisa Kohout, Josh Freeh, James Fincannon, Barb McKissock and Patricia Loyselle. Many thanks to the excellent technical staff at the NASA field centers and Jet Propulsion Laboratory (JPL). There are too many to name, but Ratnakumar Bugga, Judy Jeevarajan, Koroosh Araghi, S.R. Narayan, Bill Bennett, Marshall Smart, Ken Burke, and Ian Jakupca stand tall among their peers. The excellent managerial support from John Scott, Michelle Manzo and Subbarao Surampudi is also gratefully acknowledged. Finally, the success of our major contracts with Infinity Fuel Cell and Hydrogen, Inc. and Saft, America is due in large part because of the dedication and expertise of Bill Smith and Bob Staniewicz, respectively, and their capable teams, and our battery component work is ably led by Arumugam Manthiram at the University of Texas at Austin, Christopher Lang at Physical Sciences, Inc., Ganesh Skandan at NEI Corp., Justin Golightly at Lockheed Martin Space Systems Co., Gleb Yushin at the Georgia Institute of Technology, Robert McDonald at Giner, Inc., and Boris Ravdel at Yardney Technical Products.

Level of Review: This material has been technically reviewed by technical management.

Available from

NASA Center for Aerospace Information 7115 Standard Drive

Hanover, MD 21076-1320
National Technical Information Service 5301 Shawnee Road Alexandria, VA 22312 


\title{
Energy Storage Technology Development for Space Exploration
}

\author{
Carolyn R. Mercer, Amy L. Jankovsky, Concha M. Reid, Thomas B. Miller, and Mark A. Hoberecht \\ National Aeronautics and Space Administration \\ Glenn Research Center \\ Cleveland, Ohio 44135
}

\begin{abstract}
The National Aeronautics and Space Administration is developing battery and fuel cell technology to meet the expected energy storage needs of human exploration systems. Improving battery performance and safety for human missions enhances a number of exploration systems, including un-tethered extravehicular activity suits and transportation systems including landers and rovers. Similarly, improved fuel cell and electrolyzer systems can reduce mass and increase the reliability of electrical power, oxygen, and water generation for crewed vehicles, depots and outposts. To achieve this, NASA is developing "non-flow-through" proton-exchange-membrane fuel cell stacks, and electrolyzers coupled with lowpermeability membranes for high pressure operation. The primary advantage of this technology set is the reduction of ancillary parts in the balance-of-plant - fewer pumps, separators and related components should result in fewer failure modes and hence a higher probability of achieving very reliable operation, and reduced parasitic power losses enable smaller reactant tanks and therefore systems with lower mass and volume. Key accomplishments over the past year include the fabrication and testing of several robust, small-scale non-flow-through fuel cell stacks that have demonstrated proof-of-concept. NASA is also developing advanced lithium-ion battery cells, targeting cell-level safety and very high specific energy and energy density. Key accomplishments include the development of silicon composite anodes, lithiatedmixed-metal-oxide cathodes, low-flammability electrolytes, and cell-incorporated safety devices that promise to substantially improve battery performance while providing a high level of safety.
\end{abstract}

\section{Introduction}

The National Aeronautics and Space Administration (NASA) is developing battery and fuel cell technology to meet the expected energy storage needs of human exploration systems. Improving battery performance and safety for human missions enhances a number of exploration systems, including untethered extravehicular activity (EVA) suits and transportation systems including landers and rovers. Similarly, improved fuel cell and electrolyzer systems can reduce mass and increase the reliability of electrical power, oxygen, and water generation for crewed vehicles, depots and outposts.

To achieve this, NASA is developing "non-flow-through" proton-exchange-membrane fuel cell stacks, and electrolyzers coupled with low-permeability membranes for high pressure operation. NASA is also developing rechargeable lithium-ion batteries, targeting cell-level safety and very high specific energy and energy density. The following sections outline representative human exploration mission needs for energy storage systems, and NASA's technical approach and recent accomplishments in technology development for batteries and fuel cells.

This work was based on the needs of NASA's Constellation program to return humans to the Moon in preparation for the human exploration of Mars, (Ref. 1) and is broadly applicable to a variety of exploration missions including lunar outposts, crewed missions to near-Earth objects and Mars, and human exploration using real-time robotic operations. 


\section{Mission Needs for Energy Storage}

Energy storage technologies are critically important to human exploration. Improved battery performance in cells safe enough for human missions enhances a number of exploration systems, including extending the range, duration, or capabilities of un-tethered extravehicular activity suits and transportation systems including landers and rovers. Similarly, improved fuel cell and electrolyzer systems can reduce mass and increase the reliability of electrical power, oxygen, and water generation for crewed vehicles and planetary or lunar outposts. Reducing the number of ancillary parts in the balance-of-plant should result in fewer failure modes and hence a higher probability of very reliable operation, and reduced parasitic power losses enable smaller reactant tanks and therefore systems with lower mass and volume. NASA's Constellation program identified critical mission needs for energy storage systems, targeting mission scenarios that included extended human presence on the lunar surface. These needs are described below. Note that these needs are relevant to a broad class of human exploration missions because they are also representative of the needs of crewed vehicles including landers and rendezvous craft, and mobile human operations including EVA suits, crewed rovers, and telerobotically operated systems.

\section{A. EVA Needs}

Lunar surface missions require an untethered space suit that is effectively a single person space vehicle which requires an independent power supply. Historical space suit designs and trade studies have indicated that batteries are the energy storage technology of choice. For Constellation, three requirements have very high priority: (Ref. 2) 1) $8 \mathrm{hr}$ of continuous operation to allow for uninterrupted astronaut activity without swapping out batteries; 2) the provision of sufficient energy to power all of the components needed for an effective mission; and 3) human-safe operation, with cell-level safety highly desirable. The total energy required to power fans, pumps, processors, controllers, valves, heaters and sensors for life support, electronics and processors for communications, and auxiliary equipment such as lights and cameras, is estimated at $1155 \mathrm{Wh}$ including component duty cycles, losses and margin. The desired mass allocation for a battery unit is $5 \mathrm{~kg}$ and the volume allocation is 3 liters. These batteries are expected to operate over the temperature range of 0 to $30^{\circ} \mathrm{C}$ in $1 / 6^{\text {th }}$ of Earth's gravity and be deployed

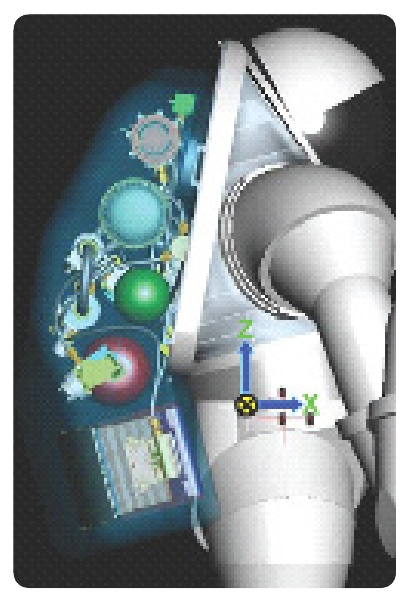

Figure 1.-Advanced EVA suits require a substantial increase in battery energy density and specific energy relative to the state-of-theart, with safety features for human operations. 
every other day for six months, requiring just 100 cycles for their expected lifetime. The resulting need is to deliver $231 \mathrm{Wh} / \mathrm{kg}$ and $373 \mathrm{Wh} / 1$ at $0{ }^{\circ} \mathrm{C}$ and a discharge rate of $\mathrm{C} / 10$ (discharge of full capacity in $10 \mathrm{hr}$ ). Current battery technologies do not meet these requirements. For reference, the lithium-ion batteries flown on the Mars Spirit and Opportunity rovers represent the state-of-the-art in flight-qualified secondary batteries, and their performance is $83 \mathrm{Wh} / \mathrm{kg}$ at $0{ }^{\circ} \mathrm{C}$ and a $\mathrm{C} / 10$ discharge rate.

\section{B. Lander Needs}

The lunar lander as envisioned by the Constellation program will be capable of landing astronauts on the Moon, providing life support and a base for initial surface exploration missions, and returning the crew to the spacecraft that will bring them home to Earth. The lander will launch aboard a rocket into low Earth orbit, where it and the Earth departure stage will rendezvous with the crew vehicle prior to being propelled toward the Moon. The lander consists of two main modules: the descent module and ascent module. Power requirements for each are as follows (Ref. 3).

For the ascent stage, advanced secondary (rechargeable) batteries are considered a critical need. The first design cycle for the lander project recommended a $14.2 \mathrm{kWh}$ primary (nonrechargeable) battery with a $67 \mathrm{~kg}$ mass, but they assumed no faults, no redundancy, and minimum ascent duration. A second design cycle considered fault management which led to the recommended use of secondary batteries to address three key risks associated with primary batteries:

1. Inability to verify proper battery function in-flight before critical use;

2. Need for instantaneous power in case of mission abort during descent requires oversized primary batteries (increasing mass); and

3. A power drop from the crew vehicle to the lander during a portion of the shadowed trans-lunar injection limits overall lander power availability.

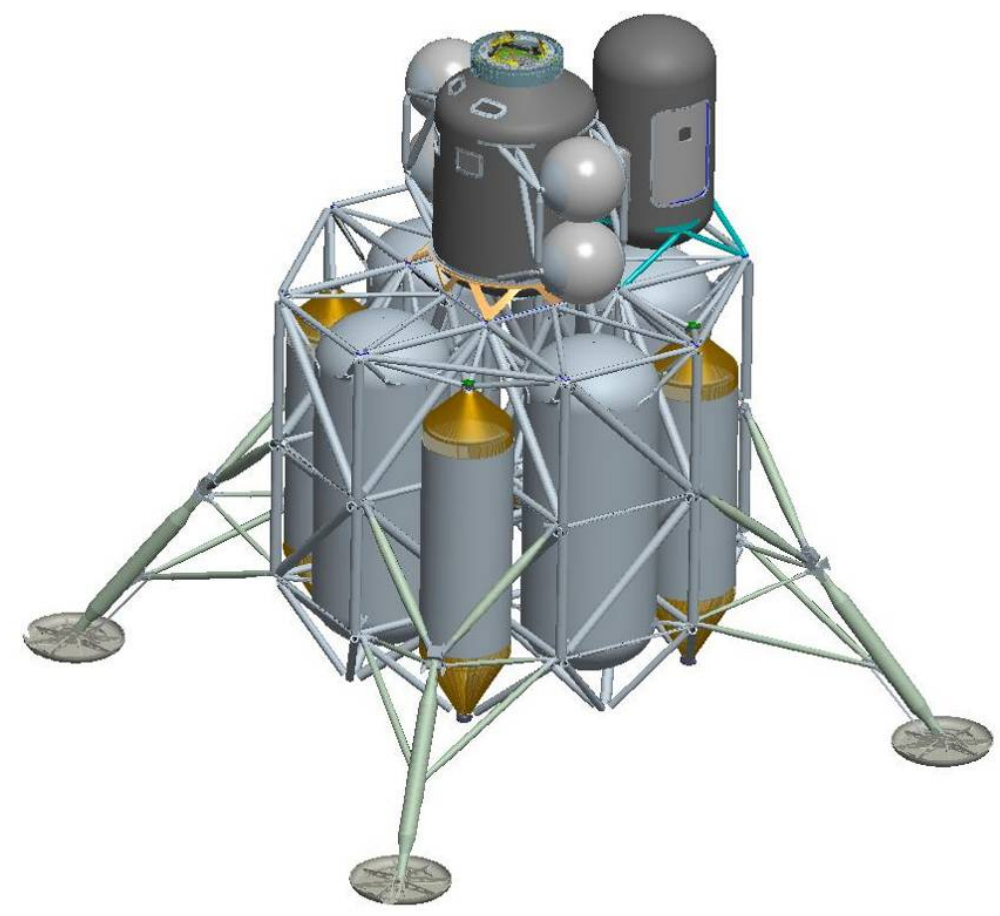

Figure 2.-A lunar lander concept would use advanced batteries to increase the ascent stage's capability, and advanced fuel cells to provide power for the descent stage. 
Operational requirements for the batteries are similar to those listed for the EVA mission: operability over 0 to $30{ }^{\circ} \mathrm{C}$ over the range of 0 to $1 \mathrm{~g}$, at a nominal full capacity discharge time of $7 \mathrm{hr}$, with only 10 cycles required for the life of the battery. Human-safe operation is required, with cell-level safety highly desirable. The mass should be comparable to a primary battery to maximize payload capability. This yields a requirement of nominally $210 \mathrm{Wh} / \mathrm{kg}$ at $0{ }^{\circ} \mathrm{C}$ and $\mathrm{C} / 10$.

For the descent stage, proton exchange membrane (PEM) fuel cells are considered enhancing. A key requirement is the ability to operate on propellant residuals while the descent stage serves as an initial lunar base for surface operations. The descent stage requires a nominal power level of $3 \mathrm{~kW}$ with $5.5 \mathrm{~kW}$ peak, operating for $220 \mathrm{hr}$ continuously. For a sortie mission, the fuel cell must provide 9 days $(216 \mathrm{hr})$ of power continuously to the lander ( 2 days during flight and 7 days on the surface). For an outpost mission, the fuel cell provides power for 3 days continuously ( 2 days in flight, 1 day on surface), then the lander is quiescent for 210 days awaiting launch. The quiescent power is supplied by the lunar surface power system, but only the ascent module needs to remain operative during that time. The lander's fuel cell will be operated until all the propellant residuals have been converted into water and power. For comparison, the alkaline fuel cells currently being flown on the Space Shuttle fleet cannot be operated on residual fuels, and have a dwindling supplier chain in the face of newly developed PEM technology.

\section{Lunar Surface Needs}

Lunar surface systems consist of habitats, mobility systems, communications and navigation, in-situ resource utilization operations, and science experiments. Regenerative fuel cells are considered enabling for lunar surface power units to provide power above normal outpost operations and to store sufficient energy to meet power usage requirements during eclipse periods. The technology needs for energy storage are based upon the results of a NASA-sponsored study which assumed an outpost established at the lunar South Pole near the rim of the Shackelton Crater (Refs. 4 and 5). At this location, insolation is available 90 percent of the time with a maximum eclipse period of $122 \mathrm{hr}$ occurring during the lunar winter (Ref. 6). In addition to providing energy storage to span this relatively long shadowed period, surface systems are expected to be robust and long-lived to minimize the number of maintenance operations and resupply launches for replacements. An operational life goal of 10,000 hr was set for the regenerative fuel cell. An additional requirement is compatibility with high pressure (2000 psi) reactant tanks to reduce the overall system volume. Low mass and operation from 0 to $1 / 6^{\text {th }} \mathrm{g}$ between 0 and $30{ }^{\circ} \mathrm{C}$ round out the requirement set. For comparison, alkaline fuel cells' 2,100 hr stack life is unacceptable in terms of maintenance requirements or operational constraints (Ref. 7).

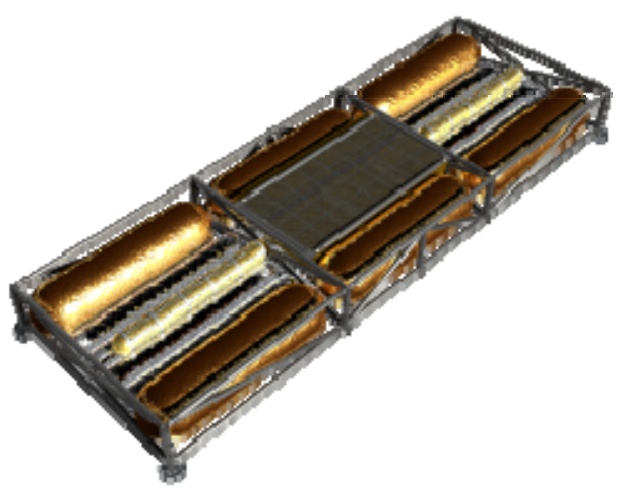

Figure 3.-Portable utility pallet concept includes a regenerative fuel cell to provide power for surface systems. 
In addition to regenerative fuel cells for stationary power, mobility systems including crewed rovers require batteries and possibly fuel cells (Ref. 8). Human-safe operation and minimal mass are the driving factors, with probable cycle requirements of nominally 2000 cycles. Four classes of mobility systems were studied for the lunar outpost: short-duration outpost traverse; long-duration small-habitat sortie; long-duration habitat transport; and long-duration un-crewed science missions. Power requirements differ for each scenario, but a representative rover carrying $3000 \mathrm{~kg}$ during a short-duration outpost traverse requires nominally $5.9 \mathrm{~kW}$ peak power, $1.15 \mathrm{~kW}$ average power and $125 \mathrm{~W}$ standby power with a nominal drive time of $87 \mathrm{hr}$ and stand-by time of $800 \mathrm{hr}$. Minimal power system mass is desired since there is an inverse relationship between battery mass and rover range and/or payload carrying ability. For batteries, this has been translated into the following goals: $150 \mathrm{Wh} / \mathrm{kg}, 10 \mathrm{hr}$ discharge and 10-hr charge, 80 percent capacity retention after approximately 2000 discharge/recharge cycles, full performance over the temperature range of 0 to $30^{\circ} \mathrm{C}$, and 5-year calendar life. As with every other human mission, safety is paramount and cell-level safety is highly desirable.

\section{Battery Technology Development}

Our technical objective for batteries is to improve the performance of secondary (rechargeable) lithium-ion cells to meet the energy storage requirements of the lander ascent stage, EVA, and lunar surface systems as described above. Our approach is to develop two types of secondary cells: a "High Energy" cell to meet lunar surface mobility needs, and an "Ultra-High Energy" cell to meet the needs of the lander and EVA suit. The former is focused on improving safety and specific energy for a mission of approximately 2000 cycles; the latter is focused on very high specific energy and energy density in a safe package for missions requiring much fewer cycles. In both cases we selected a lithium-ion chemistry because it has the best combination of safety, specific energy, technical maturity, and performance needed for the Constellation power subsystems. Whereas lithium-ion batteries are currently used for some aerospace missions, none has been qualified for use as the main energy storage element for human-rated vehicles. As such, our cell and component development efforts are directed toward improving the overall safety for lithium-ion battery systems, as well as improve their performance.

Our approach for the High Energy cells is to develop lithiated mixed-metal-oxide formulations of Ni-Mn-Co (NMC) cathodes, electrolytes that are both stable with these high voltage cathodes and flame resistant, cathode coatings to reduce exothermic reactions while retaining performance, and a thermal switch to reversibly shut down the cell if internal temperatures rise beyond unsafe levels. Our expectation is that these components, when coupled with a conventional graphite anode, will provide a cell-level specific energy of $180 \mathrm{Wh} / \mathrm{kg}$ at a discharge rate of $\mathrm{C} / 10$ at $0{ }^{\circ} \mathrm{C}$ when operated down to $3.0 \mathrm{~V}$, with 80 percent capacity retention after 2000 cycles. Furthermore, we have a goal for cell-level safety such that they will be tolerant to electrical and thermal abuse such as over-temperature (up to $110{ }^{\circ} \mathrm{C}$ ), overcharge (100 percent overcharge at $1 \mathrm{C})$, reversal (150 percent excess discharge at 1C), external short circuit, and tolerant to internal shorts (pass simulated short test) with no fire or thermal runaway.

Our approach for the Ultra-High Energy cells is to develop silicon-composite anodes to be used instead of the graphite anode in combination with the components being developed for the High Energy cells (Ref. 9). Our expectation is that this advanced anode will substantially increase the cell-level specific energy (to $260 \mathrm{Wh} / \mathrm{kg}$ at the same conditions and with the same level of safety) but will be operable for fewer cycles (only 200 cycles with 80 percent capacity retention).

The corresponding battery-level performance expectations are 150 and $220 \mathrm{Wh} / \mathrm{kg}$ for the High Energy and Ultra-High Energy designs, respectively, assuming lightweight battery packaging. Figure 4 shows how individual components are formed into battery cells.

Figure 5 depicts the individual components that we are developing for the High Energy (all components shown except the anode) and Ultra-High Energy cell (all components). These components are being developed in a variety of specialized laboratories across the country, with the integration function being done by NASA with the help of Saft, America. 


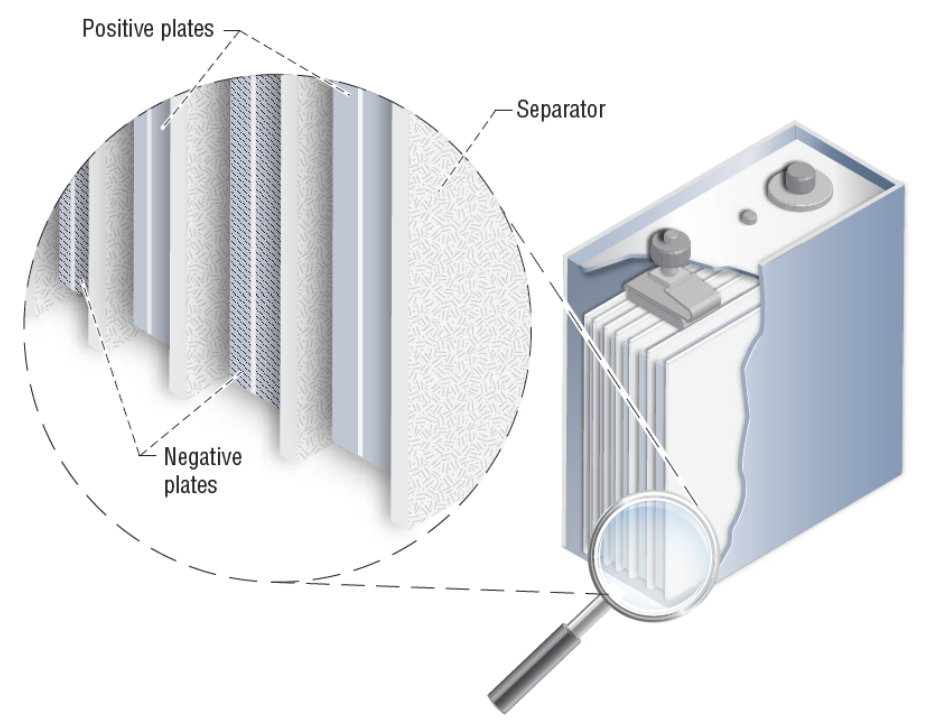

Figure 4.-Schematic showing components within a battery cell: negative plates (anode), positive plates (cathode), and separator. Electrolyte fills the void between electrodes.

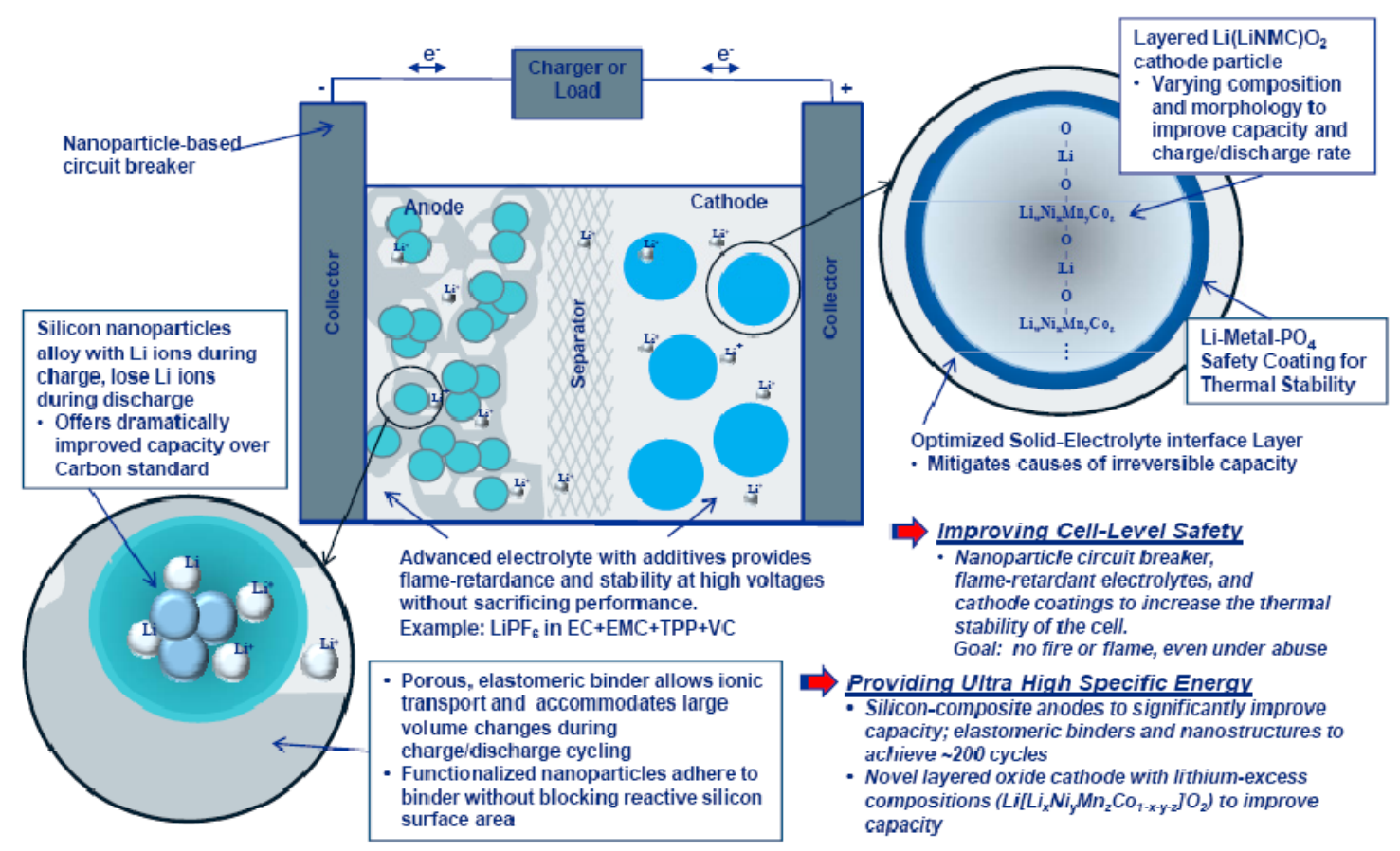

Figure 5.-Summary of component technology development for lithium-ion batteries.

Early in the development cycle we are infusing the experience of a battery manufacturer to ensure the practicality of our products, including the ability to be scaled-up to sufficient quantities and to be incorporated into industrial processes. The integration function is particularly important because many elements of component performance cannot be determined in isolation. Tests in electrochemical half-cells provide baseline information about new component performance against pure lithium electrodes; components that look sufficiently promising move on to full-cell testing against the most representative components available. This information will help us downselect to the best components and build evaluation cells using those components to determine the best combination to meet exploration needs. 


\section{A. Technical Accomplishments}

Silicon-composite anodes were chosen because of their very high theoretical capacity. This theoretical capacity is possible because of the large amount of lithium that can be transported into and out of the material during charge and discharge. However, this same feature causes a large volumetric expansion and contraction that rapidly degrades the material and limits cycle life. Working with Lockheed Martin, a team from the Georgia Institute of Technology and Clemson University, and the NASA Glenn Research Center, we are developing functionalized nanoparticles, nanosilicon structures and elastomeric binders to retain high capacity performance even after cycling. Accomplishments to date include exceeding our target goal of $1000 \mathrm{mAh} / \mathrm{g}$ at $0{ }^{\circ} \mathrm{C}$ and $\mathrm{C} / 10$ for 10 cycles in half cells, and for 40 cycles at room temperature. Less than 10 percent degradation in capacity was observed at $0{ }^{\circ} \mathrm{C}$ relative to room temperature. Full-cell testing with an NMC cathode showed excellent performance $(>1000 \mathrm{mAh} / \mathrm{g})$ through all cycles tested to date $(5 \mathrm{cycles})$ at room temperature. The challenge ahead lies in increasing the number of charge/discharge cycles to the goal value of 200 and decreasing irreversible capacity loss.

Lithiated mixed-metal-oxide cathodes were chosen because of their good thermal stability for high voltage operation. Working with the University of Texas at Austin, NEI Corporation, (Ref. 10) and the Jet Propulsion Laboratory, (Ref. 11) we are determining the proper stoichiometry to provide a high specific capacity and low irreversible capacity loss, and the proper morphology to improve rate capability. Results to date show good stability over a wide operating voltage window ( 4.8 to $2.5 \mathrm{~V}$ ), and a metal oxide coating that has increased the capacity and reduced the irreversible capacity loss. Initial batches of material have specific capacities that exceeded $250 \mathrm{mAh} / \mathrm{g}$ at room temperature and $\mathrm{C} / 10$, however their low tap density $\left(0.8 \mathrm{~g} / \mathrm{cm}^{3}\right)$ prevented their incorporation into a manufacturing process for cell fabrication. Subsequent materials have reasonable tap density (above $2.0 \mathrm{~g} / \mathrm{cm}^{3}$ ) but are so far limited to $\sim 230 \mathrm{mAh} / \mathrm{g}$ at room temperature and $\mathrm{C} / 10$. Low temperature performance is a challenge, with $\sim 30$ percent capacity reduction observed at $0{ }^{\circ} \mathrm{C}$ as compared to room temperature. Our goal is $280 \mathrm{mAh} / \mathrm{g}$ at $0{ }^{\circ} \mathrm{C}$ and $\mathrm{C} / 10$; compare this to the state-of-the-art Mars Exploration Rover batteries which have $180 \mathrm{mAh} / \mathrm{g}$ at these conditions.

Our requirements for electrolytes include compatibility with our electrodes, particularly providing stable operation up to $5.0 \mathrm{~V}$ for compatibility with the NMC cathodes. We also want reduced flammability to achieve our safety goal of tolerance to electrical and thermal abuse. Working with the Jet Propulsion Laboratory (Ref. 12) and a team from Yardney Technical Products and the University of Rhode Island, we are developing $\mathrm{LiPF}_{6}$-based materials with flame-retardant additives and nonflammable solvents. Accomplishments to date include a formulation that showed less than half of the heat release compared to a baseline electrolyte, resulting in a pressure rise of less than 25 percent compared to the baseline, and extinguished itself significantly faster than the baseline during a flame test. This formulation showed excellent electrical performance in a full cell fabricated with a nickel cobalt aluminum (NCA) cathode and graphitic anode, but the performance degraded when an NMC cathode was used. Performance with this representative cathode was restored with the addition of Lithium bis (oxalate) borate $(\mathrm{LiBOB})$ to the electrolyte, and the $\mathrm{LiBOB}$ is expected to improve the self-extinguishing effect because it aids in the passivation of the electrode.

Under electrical and/or thermal abuse conditions, exothermic reactions can occur between the cathode and electrolyte leading potentially to thermal runaway or other serious safety conditions. We are developing two devices purely to improve the safety of the cells: a cathode coating to improve thermal stability, and a composite thermal switch to break the electrical circuit if the cell's internal temperature rises too high. Working with Physical Sciences, Inc. (Ref. 13) and the NASA Johnson Space Center, (Ref. 14) we are developing a lithium metal phosphate coating to increase the onset temperature of the exothermic reactions, or suppress them altogether. This coating has shown excellent exothermic suppression on lithium cobalt oxide $\left(\mathrm{LiCoO}_{2}\right)$ cathodes, with robust adhesion and good capacity retention after 200 cycles. A recent test demonstrated that the coating can diminish heat release on high-voltage cathodes as well, without reducing performance. Work continues to determine the coating's compatibility with the NASA-developed cathode and electrolyte. Working with Giner, Inc. and the Johnson Space 
Center we are developing a nanostructured thermal switch to reversibly "turn off" the cell if the internal temperature increases beyond a safe threshold. The switch consists of a coating deposited on either electrode's current collector (see Fig. 5). The coating is normally electrically conductive, but its resistance rises very quickly when the coating is above threshold value. The basic principle for this device has been observed, but work is underway to develop reliable and repeatable operation.

A cell/battery modeling tool has been developed to aid in component materials assessments. Projected cell level performance using data from the best components shows that the High Energy cell should reach $199 \mathrm{Wh} / \mathrm{kg}$ at room temperature and beginning-of-life. Predicted performance at $0{ }^{\circ} \mathrm{C}$ falls off substantially however, to $100 \mathrm{Wh} / \mathrm{kg}$, primarily because of the poor low-temperature cathode performance. Similarly, the predicted Ultra High Energy cell-level performance is $213 \mathrm{Wh} / \mathrm{kg}$ at room temperature but drops to $100 \mathrm{Wh} / \mathrm{kg}$ at $0{ }^{\circ} \mathrm{C}$, again because of the cathode. Note that neither cycle performance nor safety can be predicted for either cell design. These results are summarized in Table 1. Note that the cell-level goal of $180 \mathrm{Wh} / \mathrm{kg}$ corresponds to $150 \mathrm{Wh} / \mathrm{kg}$ at the battery level, and $260 \mathrm{Wh} / \mathrm{kg}$ at the cell level corresponds to $220 \mathrm{Wh} / \mathrm{kg}$ at the battery level.

TABLE 1.-CELL-LEVEL PERFORMANCE PREDICTIONS FOR ADVANCED LITHIUM-ION BATTERIES

\begin{tabular}{|l|c|c|c|}
\hline \multicolumn{1}{|c|}{ Cell type } & $\begin{array}{c}\text { Cell-level performance goal } \\
\text { (at C/10 and } 0{ }^{\circ} \mathrm{C} \text { discharged to } 3.0 \mathrm{~V} \text { ) }\end{array}$ & $\begin{array}{c}\text { Predicted cell-level } \\
\text { performance } \\
\text { (at C/10 and } 23{ }^{\circ} \mathrm{C} \text { to } 3.0 \mathrm{~V} \text { ) }\end{array}$ & $\begin{array}{c}\text { Predicted cell-level } \\
\text { performance } \\
\text { (at C/10 and } 0{ }^{\circ} \mathrm{C} \text { to } 3.0 \mathrm{~V} \text { ) }\end{array}$ \\
\hline High energy & 165 to $180 \mathrm{Wh} / \mathrm{kg}$ & $199 \mathrm{Wh} / \mathrm{kg}$ & $100 \mathrm{Wh} / \mathrm{kg}$ \\
\hline Ultra high energy & 180 to $260 \mathrm{Wh} / \mathrm{kg}$ & $213 \mathrm{Wh} / \mathrm{kg}$ & $100 \mathrm{Wh} / \mathrm{kg}$ \\
\hline
\end{tabular}

\section{Fuel Cell Technology Development}

Our technical objectives for fuel cells are to: 1) increase system lifetimes and reduce system mass, volume and parasitic power loads; 2) enable the use of scavenged propellants as a fuel cell reactant; and 3 ) ensure compatibility with high pressure reactants to meet the needs of the lunar surface systems and lander descent stage as described in Section I. Our approach is to develop advanced proton-exchangemembrane (PEM) fuel cells because they have the best combination of safety, technical maturity, compatibility with scavenged propellant, and performance needed for the Constellation power subsystems.

To reduce system mass, volume and parasitic power, and increase system lifetimes for both primary and regenerative fuel cells, we are addressing the largest source of system failures and parasitic power losses: the balance-of-plant (Ref. 15). Because we will be operating in the space environment, we are using pure oxygen rather than air as a reactant. This frees us from having to remove the nonoxygen elements of air from the system, and permits the use of capillary action to remove product water. There are no recirculating reactants, and hence no requirement for providing either recirculation or external product water separation from two-phase reactant streams. Therefore, there is no need for the major components that provide these functions, and no resulting weight, volume, parasitic power, reliability, life, or cost penalties. These no-longer-needed components include water management pumps, water/gas separators, and injectors/ejectors for recirculation. As these are the system components most likely to fail, we are more likely to reach our $10,000 \mathrm{hr}$ of maintenance-free autonomous operation without them. These components can also comprise 25 to 35 percent of total system mass, and contribute parasitic losses that reduce system efficiency and therefore require more reactants for a given mission. More reactants require bigger tanks which further increase the systems mass so their elimination offers a major advantage for launched systems. Since reactant recirculation is not required, this system is a "non-flow-through" design reminiscent of the fuel cell used during NASA's successful Project Gemini missions in the 1960's (Ref. 16). Figure 6 shows a progression of the space-flight fuel cell technology since the Space Shuttle. 


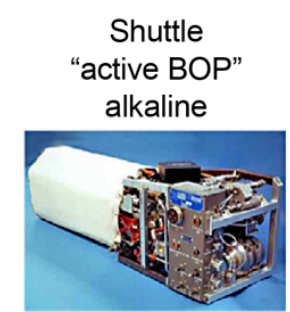

Flow-through
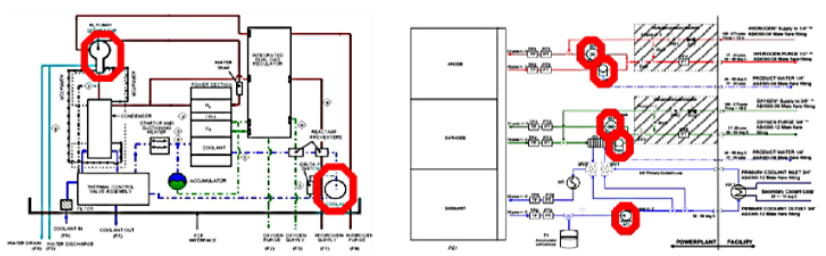

$\mathrm{O}=\begin{aligned} & \text { Active mechanical component } \\ & \text { (pump, active water separator) }\end{aligned}$
"Passive BOP"

PEM

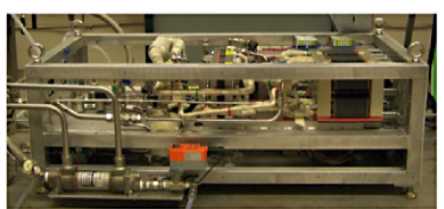

Flow-through

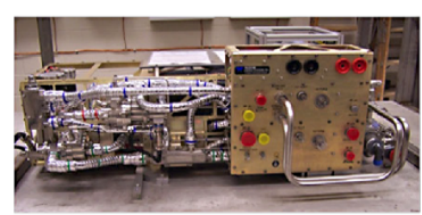

Flow-through
"Passive BOP"

PEM

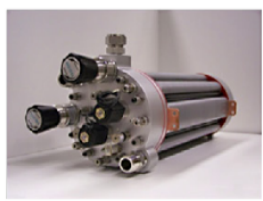

Non-flow-through

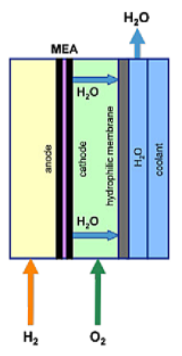

Passive mechanical component (injector/ejector, passive water separator)

Figure 6.-Progression of space-flight fuel cell technology development. Note that the right-most two schematics do not include cooling diagrams.

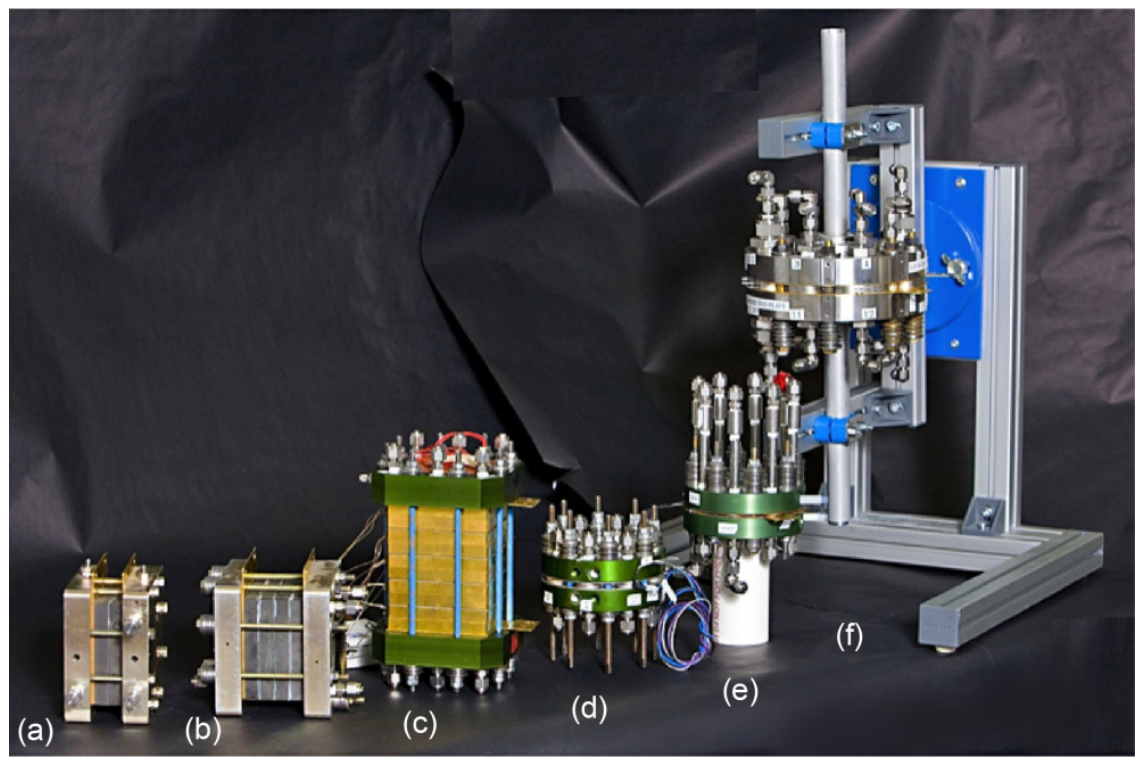

Figure 7.-Non-flow-through hardware progression. Photo courtesy of Infinity Fuel Cell and Hydrogen, Inc.

\section{A. Technical Accomplishments}

Several non-flow-through fuel cell stacks have now been built by Infinity Fuel Cell and Hydrogen, Inc. and are shown in Figure 7. These stacks have been used to methodically buy down risks associated with this new technology. The first stacks had a small active area $\left(50 \mathrm{~cm}^{2}\right.$ cross section $)$ and only a small number of cells in the stack (Fig. 7(a) and (b) have 1 and 4 cells, respectively). These stacks were relatively inexpensive and permitted the fabrication and testing of several designs to determine initial feasibility and performance parameters. 
Although non-flow-through technology will eliminate ancillary components associated with reactant flow management, the thermal management system for the primary fuel cell and electrolyzer also requires ancillary components. To increase their lifetimes, we have developed passive thermal management technologies to replace current active pumped liquid coolant loops. These technologies include pyrolytic graphite plates and flat-plate heat pipes for direct insertion into fuel cell and electrolysis stacks, replacing individual cell coolant cavities if necessary (Ref. 17). A stack (Fig. 7(c)) was built incorporating flat-plate heat pipes to test a passive thermal management concept. Although testing demonstrated that the heat pipes successfully cooled the stack, a new manufacturing technology that greatly reduces the thickness of each cell may preclude the need for the relatively expensive heat pipes. Stacks manufactured with the new process are shown in Figure 7(d) and (e), again with a small active area to test out new ideas. A stack with a $150 \mathrm{~cm}^{2}$ active area is shown in Figure 7(f). This is the expected final cross-sectional size for use by the lander and lunar surface systems, designed for $120 \mathrm{~V}$ operation.

Another area of emphasis is developing electrolyzers that operate effectively with both hydrogen and oxygen at pressures of $\sim 2000$ psi. This is being driven by the determination that high-pressure storage is necessary to meet the volume constraints for the worst-case requirement at the South Pole (120 hr eclipse at Shackleton crater with $200 \mathrm{kWh}$ required from the regenerative fuel cell). Generating the gas at high pressure rather than compressing low-pressure products improves system round-trip electrical efficiency by avoiding inefficient gas compression, thereby reducing the requirements levied on the solar power units on the lunar surface. Architecture considerations require the electrolyzer to operate in a balanced high-pressure state, placing severe constraints on stack designs; for instance, round cells rather than square may be required to minimize hoop stresses, pressurized containers or retaining rings are required for strength, and high-pressure seals, tie rods and end plates are needed. We are paying special attention to the method of supplying reactant water to the individual electrolysis cells within a stack. Candidate options include water feed as either a liquid or vapor, on either the hydrogen or oxygen sides of the cell. These different options result in different requirements for ancillary components. Operational considerations, such as managing the humidity levels in the reactant product gases, are also being considered.

Finally, Membrane Electrode Assemblies (MEAs) are a key electrochemical component within all PEM fuel cell and electrolysis stacks. The physical characteristics of the MEA, its chemical composition and catalyst formulations, all play a role in determining its electrical performance and durability. The better the electrical performance of any given MEA, the less reactants required to produce that electrical performance, and the lower the mass and volume requirements for the reactants and their respective storage tanks (e.g., every 5 percent improvement in electrical performance translates directly into a 5 percent reduction in mass and volume of reactants and storage tanks). We are developing MEAs by improving catalyst formulations and are incorporating these membranes into primary PEM fuel cell stacks and electrolysis stacks.

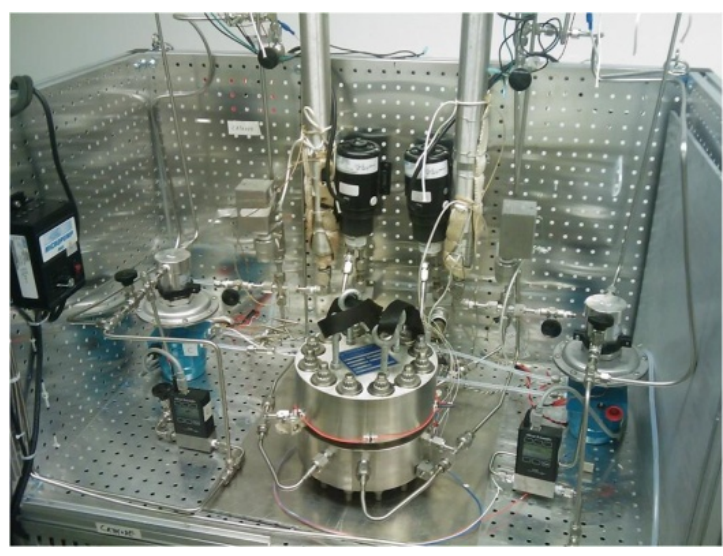

Figure 8.-High pressure electrolyzer in test stand.

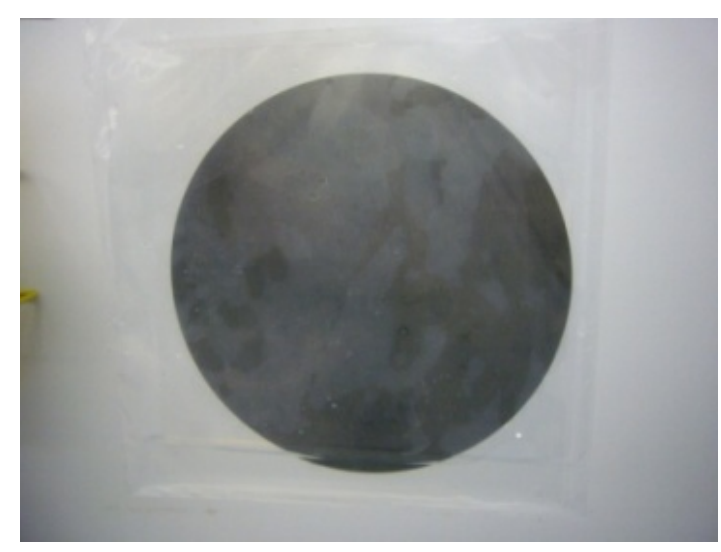

Figure 9.-MEA with platinum-black catalyst on hydrogen side and iridium oxide catalyst on oxygen side. 


\section{Conclusions}

Advanced battery and fuel cell technologies are considered critical by NASA's Constellation program to provide energy storage for EVA missions, the lunar lander, and lunar surface systems applications. Significant technical progress has been made in the development of lithium-ion battery components and non-flow-through fuel cell systems. These advancements offer the promise of greatly improving the specific energy and safety of batteries, and of substantially improving the reliability and efficiency of fuel cell and regenerative fuel cell systems for a variety of human exploration missions. These missions can include planetary outposts, crewed missions to near-Earth objects and Mars, and human exploration using real-time robotic operations.

\section{References}

1. National Aeronautics and Space Administration, "Exploration Systems Architecture Study - Final Report," NASA/TM-2005-214062, 2005.

2. Kohout, L. and Schmitz, P., Battery Trade Studies for the Portable Life Support System (PLSS) Final

Report, Sept 2008. Archived with the NASA Exploration Technology Development Program, Extravehicular Activity Technologies Project as ETDP-EVA-PCAI-004.

3. Kohout, L.L. "Power System Trade Studies for the Lunar Surface Access Module," NASA/TM-2008215179, 2008.

4. Op. cit. NASA/TM-2005-214062, 2005, Chap. 4.

5. Kerslake, T.W., "Electric Power System Technology Options for Lunar Surface Missions," NASA/TM-2005-213629, 2005.

6. Freeh, J.E., "Analysis of Stationary, Photovoltaic-Based Surface Power System Designs and the Lunar South Pole," NASA/TM-2009-215506.

7. National Research Council Committee on Space Shuttle Upgrades, Upgrading the Space Shuttle, National Academy Press, Washington DC, 1999, Chap. 4.

8. Burke, K.A., "Small Portable PEM Fuel Cell Systems for NASA Exploration Missions," NASA/TM2005-213994, 2005.

9. Reid, C.M., "A Study on Advanced Lithium-Based Battery Cell Chemistries to Enhance Lunar Exploration Missions," $11^{\text {th }}$ Electrochemical Power Sources R\&D Symposium, Baltimore, MD, July 13-16, 2009.

10. Hagh, H.M., Moorthi, M., Skandan, G., West, W., Bugga, R., and Meg, S., "Structure-Property Relationship in Electrode Materials for Li-ion Battery Applications," Materials Research Society Spring Meeting, San Francisco, CA, April 6-8, 2010.

11. West, W.C., Soler, J., Smart, M., and Ratnakumar, B.V., " $\mathrm{Li}_{2} \mathrm{MNO}_{3}-\mathrm{LiMO}_{2}$ (M=Mn, Co, Ni) Solid Solutions With Surface Coatings to Improve Li-ion Cathode Performance," Materials Science \& Technology Meeting, Houston, TX, October 2010.

12. Bugga, R. Smart, M. and West, W., "Development of Materials for Advanced Lithium-ion Batteries for NASA's Future Missions," Materials Science \& Technology Meeting, Pittsburgh, PA, Octoboer 2009.

13. Lang, C.M. and Newman, A. "Metal Phosphate Coating for Improved Cathode Material Safety," Central Regional Meeting of the American Chemical Society, Cleveland, OH, May 20-23, 2009.

14. Jeevarajan, J., "The Use of Nanomaterials to Achieve NASA's Exploration Program Power Goals," $1^{\text {st }}$ International Symposium on NanoTechnology, Energy and Space Symposium, Houston, TX, October 2009.

15. Hoberecht, M.A., "A Comparison of Flow-Through Versus Non-Flow-Through Proton Exchange Membrane Fuel Cell Systems for NASA's Exploration Missions," NASA/TM-2010-216107.

16. NASA Johnson Space Center, "Fuel Cell Technology Program Final Report," Contract NAS9-11033, September 1971.

17. Burke, K.A., "Advanced Fuel Cell System Thermal Management for NASA Exploration Missions," NASA/TM-2009-215426, 2009. 


\begin{tabular}{|c|c|c|}
\hline \multicolumn{2}{|c|}{ REPORT DOCUMENTATION PAGE } & $\begin{array}{l}\text { Form Approved } \\
\text { OMB No. 0704-0188 }\end{array}$ \\
\hline \multicolumn{3}{|c|}{ 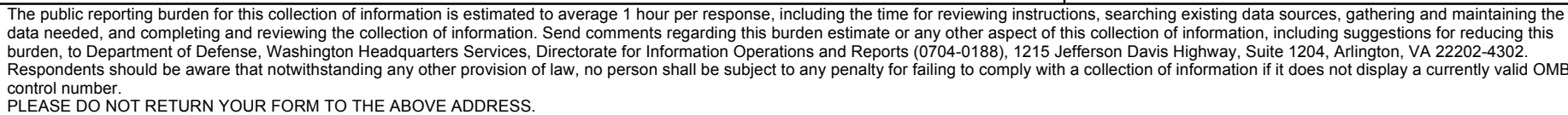 } \\
\hline $\begin{array}{l}\text { 1. REPORT DATE (DD-MM-YYYY) } \\
01-01-2011\end{array}$ & \begin{tabular}{|l} 
2. REPORT TYPE \\
Technical Memorandum
\end{tabular} & 3. DATES COVERED (From - To) \\
\hline \multirow{3}{*}{\multicolumn{2}{|c|}{$\begin{array}{l}\text { 4. TITLE AND SUBTITLE } \\
\text { Energy Storage Technology Development for Space Exploration }\end{array}$}} & 5a. CONTRACT NUMBER \\
\hline & & 5b. GRANT NUMBER \\
\hline & & 5c. PROGRAM ELEMENT NUMBER \\
\hline \multirow{3}{*}{\multicolumn{2}{|c|}{$\begin{array}{l}\text { 6. AUTHOR(S) } \\
\text { Mercer, Carolyn, R.; Jankovsky, Amy, L.; Reid, Concha, M.; Miller, Thomas, B.; Hoberecht, } \\
\text { Mark, A. }\end{array}$}} & 5d. PROJECT NUMBER \\
\hline & & 5e. TASK NUMBER \\
\hline & & $\begin{array}{l}\text { 5f. WORK UNIT NUMBER } \\
\text { WBS } 038957.01 .01 .03\end{array}$ \\
\hline \multicolumn{2}{|c|}{$\begin{array}{l}\text { 7. PERFORMING ORGANIZATION NAME(S) AND ADDRESS(ES) } \\
\text { National Aeronautics and Space Administration } \\
\text { John H. Glenn Research Center at Lewis Field } \\
\text { Cleveland, Ohio 44135-3191 }\end{array}$} & $\begin{array}{l}\text { 8. PERFORMING ORGANIZATION } \\
\text { REPORT NUMBER } \\
\text { E-17569 }\end{array}$ \\
\hline \multirow{2}{*}{\multicolumn{2}{|c|}{$\begin{array}{l}\text { 9. SPONSORING/MONITORING AGENCY NAME(S) AND ADDRESS(ES) } \\
\text { National Aeronautics and Space Administration } \\
\text { Washington, DC 20546-0001 }\end{array}$}} & $\begin{array}{l}\text { 10. SPONSORING/MONITOR'S } \\
\text { ACRONYM(S) } \\
\text { NASA }\end{array}$ \\
\hline & & $\begin{array}{l}\text { 11. SPONSORING/MONITORING } \\
\text { REPORT NUMBER } \\
\text { NASA/TM-2011-216964 }\end{array}$ \\
\hline \multicolumn{3}{|c|}{$\begin{array}{l}\text { 12. DISTRIBUTION/AVAILABILITY STATEMENT } \\
\text { Unclassified-Unlimited } \\
\text { Subject Categories: } 20 \text { and } 44 \\
\text { Available electronically at http://www.sti.nasa.gov } \\
\text { This publication is available from the NASA Center for AeroSpace Information, 443-757-5802 }\end{array}$} \\
\hline
\end{tabular}

\section{SUPPLEMENTARY NOTES}

\section{ABSTRACT}

The National Aeronautics and Space Administration is developing battery and fuel cell technology to meet the expected energy storage needs of human exploration systems. Improving battery performance and safety for human missions enhances a number of exploration systems, including un-tethered extravehicular activity suits and transportation systems including landers and rovers. Similarly, improved fuel cell and electrolyzer systems can reduce mass and increase the reliability of electrical power, oxygen, and water generation for crewed vehicles, depots and outposts. To achieve this, NASA is developing "non-flow-through" proton-exchange-membrane fuel cell stacks, and electrolyzers coupled with low-permeability membranes for high pressure operation. The primary advantage of this technology set is the reduction of ancillary parts in the balance-of-plant - fewer pumps, separators and related components should result in fewer failure modes and hence a higher probability of achieving very reliable operation, and reduced parasitic power losses enable smaller reactant tanks and therefore systems with lower mass and volume. Key accomplishments over the past year include the fabrication and testing of several robust, small-scale non-flow-through fuel cell stacks that have demonstrated proof-of-concept. NASA is also developing advanced lithiumion battery cells, targeting cell-level safety and very high specific energy and energy density. Key accomplishments include the development of silicon composite anodes, lithiated-mixed-metal-oxide cathodes, low-flammability electrolytes, and cell-incorporated safety devices that promise to substantially improve battery performance while providing a high level of safety.

\section{SUBJECT TERMS}

Lithium batteries; Electric batteries; Storage batteries; Fuel cells; Hydrogen oxygen fuel cells; Regenerative fuel cells;

Electrochemical cells; Energy storage

\begin{tabular}{|c|c|c|c|c|c|}
\hline \multicolumn{3}{|c|}{ 16. SECURITY CLASSIFICATION OF: } & \multirow{2}{*}{$\begin{array}{l}\text { 17. LIMITATION OF } \\
\text { ABSTRACT } \\
\text { UU }\end{array}$} & \multirow{2}{*}{$\begin{array}{l}\text { 18. NUMBER } \\
\text { OF } \\
\text { PAGES } \\
18\end{array}$} & \multirow{2}{*}{$\begin{array}{l}\text { 19a. NAME OF RESPONSIBLE PERSON } \\
\text { STI Help Desk (email:help@sti.nasa.gov) } \\
\text { 19b. TELEPHONE NUMBER (include area code) } \\
\text { 443-757-5802 }\end{array}$} \\
\hline $\begin{array}{l}\text { a. REPORT } \\
\text { U }\end{array}$ & $\begin{array}{l}\text { b. ABSTRACT } \\
\text { U }\end{array}$ & $\begin{array}{l}\text { c. THIS } \\
\text { PAGE } \\
\text { U }\end{array}$ & & & \\
\hline
\end{tabular}



